\title{
Rasio Spermatozoa X:Y dan Kualitas Sperma pada Kambing Kacang dan Peranakan Ettawa
}

\author{
Sigit Bintara \\ Fakultas Peternakan Universitas Gadjah Mada Yogyakarta \\ Jl. Fauna 3 Bulaksumur, 55281 Yogyakarta \\ E-mail: sigitbintara@gmail.com
}

\begin{abstract}
ABSTRAK
Penelitian ini bertujuan untuk mengetahui perbedaan rasio spermatozoa $\mathrm{X}: \mathrm{Y}$ dan kualitas sperma pada kambing Kacang dan Peranakan Ettawa. Penelitian dilaksanakan di Laboratorium Fisiologi dan Reproduksi Ternak, Fakultas Peternakan, Universitas Gadjah Mada selama tiga bulan yaitu pada bulan Desember 2009 sampai Februari 2010. Materi yang digunakan dalam penelitian ini adalah sperma dari enam ekor kambing Peranakan Ettawa umur dua tahun dengan berat 31,5 $\pm 2,2 \mathrm{~kg}$ dan enam ekor kambing Kacang umur dua tahun dengan berat 18,0 $22,1 \mathrm{~kg}$. Penampungan sperma menggunakan metode vagina buatan dengan frekuensi penampungan untuk masing-masing ternak adalah dua kali seminggu dan diulang sebanyak delapan kali. Sperma hasil penampungan segera dievaluasi kualitas dan kuantitasnya meliputi volume, konsentrasi, motilitas, viabilitas dan abnormalitas. Untuk menentukan rasio spermatozoa $\mathrm{X}: \mathrm{Y}$, spermatozoa dibuat preparat apus lalu dilakukan pengukuran kepala spermatozoa menggunakan ScionImage software. Hasil pengukuran digunakan untuk identifikasi spermatozoa $\mathrm{X}$ atau Y. Spermatozoa yang mempunyai ukuran kepala di atas rata-rata diidentifikasikan sebagai spermatozoa $X$ dan spermatozoa yang mempunyai ukuran kepala lebih kecil dari rata-rata diidentifikasi sebagai spermatozoa Y. Hasil penelitian menunjukkan bahwa rasio spermatozoa X:Y pada kambing Peranakan Ettawa (50,6 $\pm 1,8 / 49,4 \pm 1,8 \%)$ tidak berbeda nyata dengan rasio spermatozoa $\mathrm{X}$ :Y kambing Kacang

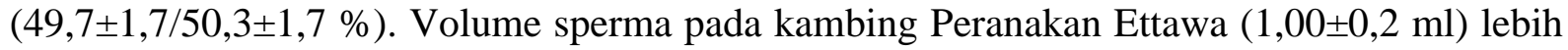
tinggi $(\mathrm{P}<0,05)$ daripada volume sperma pada kambing Kacang $(0,62 \pm 0,2 \mathrm{ml})$. Konsentrasi sperma pada kambing Peranakan Ettawa (2.865 \pm 431 juta/ml) tidak berbeda nyata dibandingkan konsentrasi sperma pada kambing Kacang $(2.840 \pm 383$ juta/ml). Motilitas spermatozoa pada kambing Peranakan Ettawa $(66,7 \pm 9,8 \%)$ lebih tinggi $(\mathrm{P}<0,05)$ daripada motilitas spermatozoa pada kambing Kacang (50,0 $\pm 7,1 \%)$. Viabilitas spermatozoa pada kambing Peranakan Ettawa $(80,0 \pm 7,1 \%)$ lebih tinggi $(\mathrm{P}<0,05)$ daripada viabilitas spermatozoa pada kambing Kacang (67,5 $\pm 9,4 \%$ ). Abnormalitas spermatozoa pada kambing Peranakan Ettawa (8,2 $\pm 3,3$ \%) tidak berbeda nyata dibandingkan abnormalitas spermatozoa pada kambing Kacang (8,6 $\pm 2,4 \%$ ). Dari penelitian ini dapat disimpulkan bahwa bangsa kambing Peranakan Ettawa dan kambing Kacang memiliki rasio spermatozoa X:Y yang tidak berbeda, sedangkan volume, motilitas dan viabilitas pada kambing Peranakan Ettawa lebih baik dibandingkan dengan sperma bangsa kambing Kacang.
\end{abstract}

Kata kunci: spermatozoa XY, kualitas dan kuantitas, Peranakan Ettawa, Kacang 


\title{
Ratio of X:Y Spermatozoa and Sperm Quality of Kacang and Ettawa-Crossed Breed Goats
}

\begin{abstract}
The objective of the study was to know the difference of $X: Y$ spermatozoa ratio and sperm quality of Kacang and Ettawa-crossed breed goats. It was conducted at Laboratory of Animal Physiology and Reproduction, Faculty of Animal Science Universitas Gadjah Mada for three months, starting December 2009 to February 2010. Materials of the study were sperm collected from six two-year Ettawa-crossed breed goats weighing $31.5 \pm 2.2 \mathrm{~kg}$ and from six two-year Kacang goats weighing $18.0 \pm 2.1 \mathrm{~kg}$. The sperm was collected using artificial vagina with frequency of twice a week for each goat and it was repeated eight times. The quality and quantity of the sperm was immediately evaluated by its volume, concentration, motility, viability and abnormality. To determine the ratio of $X: Y$ spermatozoa, smear preparation was made and spermatozoa head was then measured using Scion Image software. The results of the measurement were used for identification of $X$ or $Y$ spermatozoa. Spermatozoa having bigger head than the average were identified as $X$ and those having smaller head as $Y$. The result showed that the ratio of $X: Y$ spermatozoa of Ettawa-crossed breed goats (50.6 $\pm 1.8: 49.4 \pm 1.8 \%$ ) was not significantly difference with that of Kacang goats

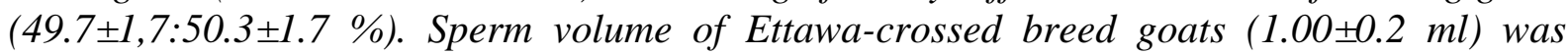
higher than that of Kacang goats $(0.62 \pm 0.2 \mathrm{ml})$. Sperm concentration of Ettawa-crossed breed goats $(2,865 \pm 431$ million $/ \mathrm{ml})$ was not significantly difference compared to that of Kacang goats $(2,840 \pm 383$ million $/ \mathrm{ml})$. Spermatozoa motility of Ettawa-crossed breed goats $(66.7 \pm 9.8 \%)$ was higher $(P<0.05)$ than that of Kacang goats $(50.0 \pm 7.1 \%)$. Spermatozoa viability of Ettawa-crossed breed goats $(80.0 \pm 7.1 \%)$ was higher $(P<0.05)$ than that of Kacang goats $(67.5 \pm 9.4 \%)$. Spermatozoa abnormality of Ettawa-crossed breed goats $(8.2 \pm 3.3 \%)$ was not significantly difference compared to that of Kacang goats $(8.6 \pm 2.4 \%)$. The study was concluded that the breeds of Ettawa-crossed breed and Kacang goats have indifferent ratio of $X: Y$ spermatozoa, while the sperm volume, motility and viability of Ettawacrossed breed goats was better than that of Kacang goats.
\end{abstract}

Key words: XY spermatozoa, quality and quantity, Ettawa-crossed breed, Kacang.

\section{PENDAHULUAN}

Ternak kambing merupakan salah satu jenis ternak yang berperan cukup besar dalam kehidupan masyarakat petani, karena ternak tersebut sangat cocok untuk dibudidayakan di tingkat pedesaan. Ternak kambing sangat potensial untuk diusahakan secara komersial antara lain karena tingkat reproduksi yang cukup baik dan daya adaptasi terhadap lingkungan yang cukup tinggi (Werdhani dan Lestari, 1996). Dewasa ini permintaan kambing terus mengalami peningkatan, termasuk permintaan untuk ekspor. Meningkatnya permintaan kambing jika tidak diikuti dengan usaha mempertahankan jumlah populasi dapat mengakibatkan populasi semakin menurun. Peningkatan permintaan kambing ini merupakan peluang yang bagus untuk meningkatkan taraf hidup peternak, namun di sisi lain akan mengancam jumlah populasi kambing. Oleh karena itu perlu diupayakan untuk mempertahankan agar jumlah populasi kambing ini tidak menurun dari waktu ke waktu. Usaha yang dapat dilakukan guna mempertahankan populasi adalah dengan mempertahankan jumlah induk. Jumlah induk dalam populasi tidak terlepas dari rasio jenis kelamin anak yang dilahirkan. Semakin banyak anak betina dilahirkan maka calon induk yang tersedia 
juga lebih banyak. Rasio atau imbangan jenis kelamin anak yang dilahirkan sangat tergantung dari rasio spermatozoa $\mathrm{X}: \mathrm{Y}$. Spermatozoa yang mengandung kromosom $\mathrm{X}$ akan menghasilkan embrio betina, sedangkan spermatozoa yang mengandung kromosom Y akan menghasilkan embrio jantan (Cupps, 1991). Jika rasio spermatozoa $\mathrm{X}$ :Y mendekati 50:50\% berarti ada proporsi yang seimbang antara jumlah kelahiran anak betina dan anak jantan. Tetapi jika rasio spermatozoa X:Y tidak mendekati 50:50\% maka akan terjadi proporsi yang tidak seimbang antara jumlah kelahiran anak betina dan anak jantan. Dan jika kelahiran anak betina lebih sedikit maka hal tersebut lambat laun akan mempengaruhi jumlah populasi jumlah induk calon induk yang semakin berkurang. Untuk itu perlu dilakukan studi mengenai rasio spermatozoa $\mathrm{X}$ :Y pada kambing, apakah masih mendekati $50: 50 \%$ ataukah sudah mengalami pergeseran.

Jumlah populasi dapat juga dipertahankan atau bahkan ditingkatkan dengan cara peningkatan reproduktivitas ternak. Dengan reproduktivitas ternak yang baik maka pertambahan jumlah ternak akan semakin cepat. Salah satu hal yang erat kaitannya dengan peningkatan reproduktivitas ternak adalah kualitas sperma. Kualitas sperma yang baik akan menghasilkan tingkat konsepsi yang tinggi, baik pada perkawinan alami maupun inseminasi buatan, sehingga akan didapatkan service per conception (S/C) yang rendah. Untuk keperluan tersebut perlu dilakukan studi mengenai kualitas sperma dari kambing-kambing yang ada di lapangan. Jika ternyata kualitas sperma kurang baik maka perlu dilakukan usaha-usaha untuk memperbaikinya, namun jika ternyata kualitas sperma sudah baik maka harus dipertahankan agar tetap baik.

Berdasarkan uraian tersebut maka perlu dilakukan penelitian untuk mengetahui perbedaan rasio spermatozoa $\mathrm{X}: \mathrm{Y}$ dan kualitas sperma pada kambing Kacang dan Peranakan Ettawa.

\section{MATERI DAN METODE}

Pada penelitian ini digunakan sperma dari enam ekor kambing Peranakan Ettawa umur 2 tahun dengan berat 31,9 2 2,2 kg, dan enam ekor kambing Kacang umur 2 tahun dengan berat $18,1 \pm 2,0 \mathrm{~kg}$.

Penampungan sperma menggunakan vagina buatan dan tabung penampung sperma Alat dan bahan yang digunakan untuk pemeriksaan sperma adalah mikroskop merk Zeizz buatan Jerman, slide warmer merk FHK buatan Jepang, gelas objek, pipet haemocytometer skala 101 merk Assistant buatan Jerman, cover glass, kamar hitung Neubauer merk Assistant buatan Jerman, handtally counter buatan Taiwan, larutan Hayem's, eosin, pipet, dan lampu pemanas. Pengukuran kepala spermatozoa menggunakan mikroskop Zeizz buatan Jerman, micrometer skala 10/100 mm merk KS buatan Jepang, kamera digital model Divi Cam merk Creative buatan Malaysia, dan komputer yang sudah terinstall perangkat lunak Scion Image.

Ternak dibagi dalam dua kelompok bangsa yaitu enam ekor kambing Kacang dan enam ekor Peranakan Ettawa. Setiap hari dilakukan penampungan sebanyak 4 ekor pejantan yaitu dua ekor bangsa kambing Kacang dan dua ekor Peranakan Ettawa. Masing-masing ternak ditampung dua kali dalam seminggu dengan delapan kali pengulangan. Sperma hasil penampungan lalu dievaluasi kualitas maupun kuantitasnya. Data yang diperoleh dianalisis menggunakan uji t (Astuti, 1980).

\section{HASIL DAN PEMBAHASAN}

\section{Rasio Spermatozoa X:Y}

Rasio spermatozoa X:Y kambing Peranakan Ettawa (50,6 $\pm 1,8: 49,4 \pm 1,8 \%)$ tidak berbeda nyata dengan rasio spermatozoa $\mathrm{X}: \mathrm{Y}$ kambing Kacang (49.7 $\pm 1,7: 50.3 \pm 1.7 \%)$ (Tabel 1). Hasil ini menunjukkan bahwa rasio spermatozoa $\mathrm{X}: \mathrm{Y}$ pada kambing Peranakan Ettawa dan kambing Kacang mendekati 50:50\%. Secara 
alamiah spermatogenesis atau proses pembentukan spermatozoa pada mahkluk hidup akan menghasilkan dua macam tipe spermatozoa $\mathrm{X}$ dan $\mathrm{Y}$ dengan imbangan yang sama yaitu $50 \%$ berbanding $50 \%$ (Bearden et al., 2004). Dari hasil tersebut dapat diprediksi bahwa jika terjadi perkawinan maka rasio jenis kelamin anak yang dilahirkan adalah imbang antara jantan dan betina, yaitu 50:50\%. Selain itu terbukti juga bahwa sejauh ini tidak terjadi pergeseran rasio jenis kelamin anak yang dilahirkan pada kambing Peranakan Ettawa dan Kacang.

Untuk dapat mengetahui rasio spermatozoa $\mathrm{X}: \mathrm{Y}$ maka perlu metode identifikasi spermatozoa, dan hal ini dapat dilakukan dengan cara yang relatif sederhana karena adanya perbedaan karakteristik antara spermatozoa X dan Y. Spermatozoa Y memiliki ukuran kepala yang lebih kecil dan berat yang lebih ringan dibandingkan dengan spermatozoa $X$, selain itu materi genetik yang dikandung spermatozoa Y lebih sedikit daripada X, sehingga menyebabkan perbedaan densitas pada kedua spermatozoa tersebut (Ericsson, 1973; White et al., 1984). Perbedaan karakteristik pada ukuran kepala tersebut dapat digunakan untuk identifikasi spermatozoa X dan Y (Afiati, 2004). Identifikasi dengan mengukur kepala spermatozoa ini sangat terbantu dengan pesatnya perkembangan teknologi komputer dewasa ini. Banyak perangkat lunak untuk mempermudah pekerjaan manusia. Salah satu perangkat lunak yang ada adalah Scion Image. Scion Image merupakan perangkat lunak yang dapat digunakan untuk mengukur dan menganalisis suatu objek gambar yang berbentuk digital (Anonimus, 2007) sehingga dapat dipakai sebagai alat bantu pengukuran kepala spermatozoa (Bintara, 2009).

\section{Volume Sperma}

Hasil analisis statistik menunjukkan bahwa volume sperma per ejakulasi kambing Peranakan Ettawa $(1,00 \pm 0,2 \mathrm{ml})$ adalah lebih tinggi $(\mathrm{P}<0,05)$ dibandingkan volume sperma kambing Kacang (0,62 $\pm 0,2$ ml) (Tabel 1). Hal ini disebabkan karena kedua bangsa kambing tersebut memiliki genetik yang berbeda dan juga ukuran tubuh kambing Peranakan Ettawa yang lebih besar daripada kambing Kacang, sebagaimana dinyatakan oleh Toelihere (1993) bahwa volume sperma per ejakulat berbeda-beda tergantung dari berbagai faktor antara lain bangsa dan ukuran tubuh.

Volume sperma per ejakulasi dari kambing Kacang dan Peranakan Ettawa yang didapat pada penelitian ini masih berada dalam kisaran rata-rata volume sperma kambing di Indonesia yaitu 0,5 sampai 1,0 ml (Devendra dan Burns, 1983), 0,6 sampai 1,0 ml (Chemineau et al., 1991), dan 0,5 sampai 1,25 ml (Hardjopranjoto, 1995).

\section{Konsentrasi Spermatozoa}

Hasil analisis statistik menunjukkan bahwa tidak terdapat perbedaan yang nyata antara konsentrasi spermatozoa kambing Kacang $(2.865 \pm 431$ juta/ml) dan Peranakan Ettawa (2.840 \pm 383 juta/ml) (Tabel 1).

Hasil yang diperoleh menunjukkan bahwa konsentrasi spermatozoa kambing tidak dipengaruhi oleh bangsa. Menurut Hafez (1993), status nutrisi dapat mempengaruhi proses spermatogenesis. Pada penelitian ini kedua kelompok bangsa kambing mendapatkan pakan dengan kualitas yang sama, sehingga didapatkan konsentrasi yang tidak berbeda. Konsentrasi spermatozoa pada kedua bangsa kambing yang didapat dalam penelitian ini masih berada pada kisaran normal yaitu yaitu 2.500 sampai 5.000 juta per ml (Evan dan Maxwell, 1987); 2.000 sampai 6.000 juta per $\mathrm{ml}$ (Hafez, 1993); 1.800 sampai 4.000 juta per $\mathrm{ml}$ (Devendra dan Burns, 1983) dan 1.5004.000 juta per ml (Hardjopranjoto, 1995).

\section{Motilitas Spermatozoa}

Hasil analisis statistik menunjukkan bahwa motilitas spermatozoa kambing 
Tabel 1. Rata-rata rasio spermatozoa X:Y, volume sperma, konsentrasi, motilitas, viabilitas dan abnormalitas spermatozoa Kambing Peranakan Ettawa dan Kacang

\begin{tabular}{lcc}
\hline \hline Variabel & Kambing Peranakan & Kambing Kacang \\
& Ettawa & \\
\hline Rasio spermatozoa X:Y (\%) & $50,6 \pm 1,8: 49,4 \pm 1,8$ & $49.7 \pm 1,7: 50.3 \pm 1.7$ \\
Volume sperma (ml) & $1,00 \pm 0,2^{\mathrm{a}}$ & $0,62 \pm 0,2^{\mathrm{b}}$ \\
Konsentrasi spermatozoa (juta/ml) & $2.865 \pm 431$ & $2.840 \pm 383$ \\
Motilitas spermatozoa (\%) & $66,7 \pm 9,8^{\mathrm{a}}$ & $50,0 \pm 7,1^{\mathrm{b}}$ \\
Viabilitas (\%) & $80,0 \pm 7,1^{\mathrm{a}}$ & $67,5 \pm 9,4^{\mathrm{b}}$ \\
Abnormalitas (\%) & $8,2 \pm 3,3$ & $8,6 \pm 2,4$ \\
\hline
\end{tabular}

a,b : Superskrip yang berbeda pada baris yang sama menunjukkan perbedaan yang nyata $(\mathrm{P}<0,05)$

Peranakan Ettawa $(66,7 \pm 9,8 \%)$ lebih tinggi $(\mathrm{P}<0,05)$ daripada motilitas spermatozoa kambing Kacang $(50,0 \pm 7,1 \%)$ (Tabel 1). Menurut Gomes (1997), motilitas spermatozoa kambing dan domba adalah $75 \%$, dan spermatozoa dikatakan masih berkualitas baik jika motilitas lebih dari 60\%. Hasil yang hampir sama juga dilaporkan Tambing et al., (2001) yang menyatakan bahwa persentase spermatozoa motil adalah 72,79\%.

Motilitas merupakan daya gerak spermatozoa yang dijadikan patokan sederhana dalam penilaian kualitas sperma untuk inseminasi buatan. Dari hasil penelitian menunjukkan bahwa motilitas sperma kambing dipengaruhi oleh bangsa ternak. Hal ini sesuai dengan pernyataan Herdis, (2005) bahwa motilitas dipengaruhi oleh perbedaan bangsa, waktu pemeriksaan dan juga ukuran tubuh. Semakin besar motilitas spermatozoa yang teramati maka semakin banyak jumlah spermatozoa yang masih bertahan hidup dan mampu bergerak.

\section{Viabilitas Spermatozoa}

Hasil analisis statistik menunjukkan bahwa viabilitas sperma kambing Peranakan Ettawa (80,0 $\pm 7,1 \%)$ lebih tinggi $(\mathrm{P}<0,05)$ daripada kambing Kacang (67,5 $\pm 9,4 \%)$ (Tabel 1).

Hasil yang diperoleh memperlihatkan bahwa bangsa ternak dapat mempengaruhi jumlah sel sperma hidup. Persentase viabilitas sperma kambing
Peranakan Ettawa lebih baik daripada kambing Kacang, karena perbedaan ternak yang diperiksa, interval penampungan, waktu pemeriksaan, ukuran tubuh, dan perubahan kesehatan reproduksi (Herdis, 2005).

Viabilitas merupakan persentase jumlah spermatozoa yang hidup (Toelihere, 1985). Meskipun hasil penelitian menunjukkan bahwa persentase viabilitas sperma dari kambing Peranakan Ettawa dengan Kacang adalah berbeda nyata namun keduanya masih berada dalam kisaran nornal dan dapat digunakan. Hal tersebut sesuai dengan pendapat Terril (1973) yang menyatakan bahwa viabilitas spermatozoa kambing diharapkan adalah 90\%, namun demikian jika viabilitas tidak kurang dari $50 \%$ masih dapat menghasilkan fertilitas yang baik, dan menurut Hardjopranjoto (1995), kualitas sperma yang baik mempunyai persentase sperma hidup yang masih tinggi dan jumlah sperma yang mati tidak lebih dari $15 \%$.

\section{Abnormalitas Spermatozoa}

Hasil analisis statistik menunjukkan bahwa tidak terdapat perbedaan yang nyata antara persentase abnormalitas sperma kambing Kacang (8,2 $\pm 3,3$ \%) dan Peranakan Ettawa (8,6 $\pm 2,4 \%$.) (Tabel 1).

Kelainan bentuk atau abnormalitas spermatozoa dapat dilihat pada kepala, badan dan ekor. Kelainan-kelainan tersebut dapat terjadi karena kelainan-kelainan pada 
tubuli seminiferi, gangguan testikuler, dan kelainan yang terjadi setelah sel atau bakal sel kelamin jantan meninggalkan epitel kecambah pada tubuli seminiferi, selama perjalanannya melalui saluran epididimis dan vas deferens, selama ejakulasi dan perjalanannya melalui urethra atau manipulasi terhadap ejakulat dan juga karena kontaminasi dengan air urine atau antiseptik (Toelihere, 1985).

Abnormalitas spermatozoa dari kedua bangsa yang didapat dari penelitian ini masih berada pada kisaran normal. Menurut Delgadillo (1992) persentase spermatozoa abnormal kambing yang sehat adalah sekitar 6\% sampai 10\%. Toelihere (1993) menambahkan, apabila selama abnormalitas belum mencapai 20\% maka masih dapat digunakan untuk inseminasi buatan.

\section{KESIMPULAN}

Berdasarkan penelitian ini dapat disimpulkan bahwa bangsa kambing Peranakan Ettawa dan kambing Kacang memiliki rasio spermatozoa $\mathrm{X}: \mathrm{Y}$ yang tidak berbeda yaitu mendekati 50:50, sedangkan volume, motilitas dan viabilitas pada kambing Peranakan Ettawa lebih baik dibandingkan dengan sperma bangsa kambing Kacang.

\section{DAFTAR PUSTAKA}

Afiati, F. 2004. Proporsi dan karakteristik spermatozoa X dan Y hasil separasi kolom albumin. Media Peternakan. Fakultas Peternakan IPB, Bogor.

Anonimus. 2007. Scion Image. http://www.scioncorp.com. Accession Date $23^{\text {th }}$ Januari 2007.

Astuti, J.M. 1980. Rancangan Percobaan dan Analisa Statistik. Fakultas Peternakan. Universitas Gadjah Mada, Yogyakarta.

Bearden, H.J., J.W. Fuquay and S.T. Willard. 2004. Applied Animal Reproduction. $6^{\text {nd }}$ Edition. Pearson Prentice Hall. Upper Saddle river, New Jersey.
Bintara, S. 2009. Peningkatan Kinerja Reproduksi Induk Kambing Bligon Melalui Seleksi Pejantan, Identifikasi dan Separasi Spermatozoa, serta Suplementasi Energi-protein. Disertasi. Universitas Gadjah Mada. Yogyakarta.

Chemineau, P., Cagnie Y., Guerin Y., Orgeur P. and Vallet J. C. 1991. Training Manual on Artificial Insemination in Sheep and Goats. Food Agriculture Organization of The United Nation. Rome, Italy.

Cupps, P.T. 1991. Reproduction in Domestic Animals. Fourth edition. Academic Press Inc. San Diego, New York, Boston, Toronto, London, Sydney, Tokyo.

Delgadillo J. J, Leboeuf B., Chemineau P. 1992. Abolition of seasonal variations in semen quality and maintenance of sperm fertilizing ability by photoperiodic cycles in goat bucks. Small Ruminant Research 9: 47-59.

Devendra, C. dan M. Burns. 1983. Produksi Kambing di Daerah Tropis. Penerbit ITB dan Penerbit Universitas Udayana.

Ericsson, R.T. 1973. Isolation and storage of progresively motile human sperm. J. Androl., 9: 111-113.

Evans, G and M.W.C. Maxwell. 1987. Salamon's Artificial Insemination of Sheep and Goat. Butterworths, Sydney.

Gomes, W. R. 1997. Artificial Insemination in : Reproduction in Domestic Animals. H.H. Cole and P.T. Cupps. Academic Press, New York, San Francisco, London.

Hafez, E.S.E. 1993. Reproduction In Farm Animal. Sixth Edition. Lea and Febiger. Philadelphia.

Hardjoprandjoto, S. 1995. Ilmu Kemajiran pada Ternak. Airlangga University Press. Surabaya.

Herdis. 2005. Optimalisasi Inseminasi Buatan Melalui Aplikasi Teknologi Laserpunktur pada Domba Garut (Ovis aries). Disertasi. Institut Pertanian Bogor. Bogor.

Tambing, N.S., Muhamad Gazali dan Bambang Purwantara. 2001. Pemberdayaan teknologi inseminasi buatan pada ternak kambing. Wartazoa Vol. 11 No. 1 Th. 2001.

Terrill, C. L. 1973. Sheep and Goats in The Artificial Insemination of Farm Animals. 
Rutgers University Press, New Bruswick, New Jersey.

Toelihere, M.R. 1985. Fisiologi Reproduksi Pada Ternak. Penerbit Angkasa, Bandung.

Toelihere, M.R. 1993. Inseminasi Buatan Pada Ternak. Penerbit Angkasa. Bandung

Werdhani, W. dan B. Lestari. 1996. Peningkatan Produksi Ternak Kambing Lokal Penghasil
Daging. Proyek IP2TP. Departemen Pertanian. Yogyakarta.

White, L.M., W.E. Beal, J.H. Bame. R.G. Saacke and C.E. Marshall. 1984. Characteristic of bovine spermatozoa after migration through a bovine serum albumin gradient. J. Anim. Sci., 59: 454-459. 